\section{一文献 -}

1) H. E. Carter, J. Biol. Chem, 139, 247 (1941).

2) D. F. Elliott, Nature, 162, 658 9 (1948); $C$. A. 43, 3786 ( 1949$)$.

3) Mc Coy, Meyer \& Rose, J. Biol. Chem., 115, 721 (1935); H. D. West, H. E. Carter, J. Biol. Chem., 119, 109 119 (1937); J. Biol.
Chem, 122, 611 (1937 38). D. F. Elliott, J. Chem. Soc., 1950, 62.

3..4) E. Fischer, K. Raske, Ber., 41, 893 (1908); J. L. Wood, L. Van Midalesworth, $\dot{\delta}$. Biol. Chem., 179, 529 (1949).

5) D. F. Elliott, J. Chem. Soc., 1949, 589 94, C. A., 43, 9083 (1949).

\title{
アンモニア-酸性白土による $\alpha$-ピネンの異性化
}

小岛英幸

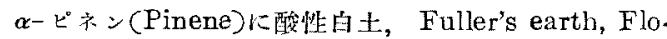
rida earth 等在锠時作用させるときは，一部はDipenー

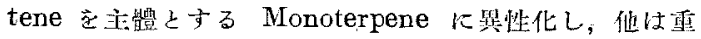
合して Diterpene 笋になり，カムフェン(Camphene)

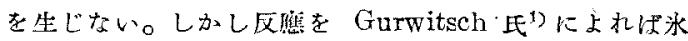

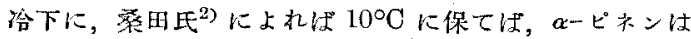
相當量力ムフェンに琵性化する。

著者は前報》に招いて，酸性白土に篮化アンモニウ ム，焤酸アンモ=ウム等を添加すれぱ， $\alpha$ ーピネンと加㷛 しても，單に酸性白土のみと處理する時の上5な重合を 括こさず， $\alpha$ ーピホンは主としてカムフェンに罢性化する ことを報告した。この際添加するアンモニウム筑は，硫 酸アンモニウムの如く高溫（約 $350^{\circ} \mathrm{C}$ )にてはじめてア ンモニアを解離する。のでは，全然酸性白土の重合作月

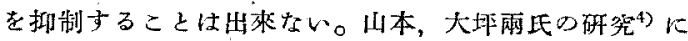

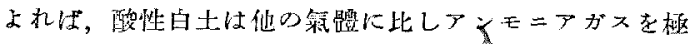
めてよく㔭着する。そ机故これはアンモニア自體が酸性 白上の重合作用を抑修する主なる原因をつくつているも の上慗像される。

アンモニアガスは相常はげしい榣熱をともなつて酸性 日土に吸䏠されるが，この結合は他の多くの氣踣と酸性 白上との結合に比してはるかた强图なるのてする。この アンモニアー酸性白上を $\propto$-ピネンとその沸點約 $155^{\circ} \mathrm{C}$ に抈熱した場合には，京吉りはつきりした鼠性化の現象 はあらす扎ない。しかし更に溫度を上けて氛相にて約 $200^{\circ} \mathrm{C}$ て處理した場合には、 $\alpha$ ーピネンは火牛かカムフェ

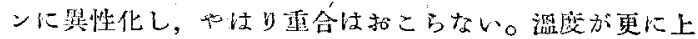

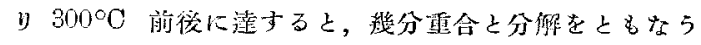
よ5になり，生成物は多種類にわたり，唓に酸性白土を aーピネンとを高溫にて處理した場合に次第に近似して來 る。

\section{茞 驗 $\dot{\infty}$ 部}

1. アンモニア-酸性由土 市眅酸性白土をフラスコ

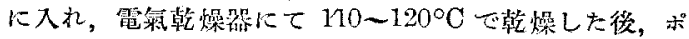
ンブにて排州し，フラスコ內に乾燥したアンモニアガス を徐々に導入する。はげしい登熱をともなつて酸性白土 にアンモニアが吸着される。充分にアンモニアを吸着し た粉狀のアンモニアー酸性白土をそのまま使用する。

氣相反㫿の場合には，こ礼を更にアンモニア水でれつ て粒狀の鋜劑となし，日光にあてて畭燥したものを使用 した。こ礼は全然アンモニア是を登しない。

II. $\alpha$-ピネン 方堁テレビン泊を紫性ソーダ溶液と 加熱處理した後，水蒸氣蒸溜に附する。溜出した精油分

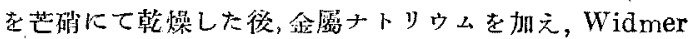
分溜管を用いて分溜を繰返す。浩點 $155 \sim 156^{\circ} \mathrm{O}$ の溜分 老 $\boldsymbol{\alpha}$ ービネンとした。

$d_{4}^{31}=0.8503, n_{\mathrm{D}}^{31}=1.4605$

Nitrosochloride: 試料 $5 \mathrm{cc}$ に亚砂酸厂ミルと氷酯酸

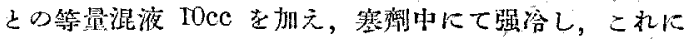

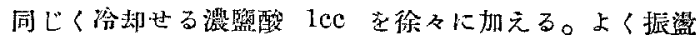
すれば白色結晶を生ず。これる滤取してアルコールにて 充分洗つた㘼乾燥する。融點 $104^{\circ} \mathrm{C}$ 。

III. アンモニア-酸性白土との加熱處理 $\alpha$-ピネン 溜分 $100 \mathrm{cc}$ を $10 \mathrm{~g}$ の粉狀アンモニアー酸性白土る $\boldsymbol{\alpha}$-ピ

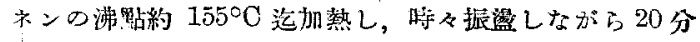
還流せしめる。酸性白土を滤去した油分を分溜する。

沸點 $155 \sim 156^{\circ} \mathrm{C}$. $50 \mathrm{cc}$ 


$\begin{array}{rr}156 \sim 157^{\circ} \mathrm{C} & 25 \mathrm{cc} \\ 157 \sim 158^{\circ} \dot{\mathrm{C}} & 10 \mathrm{cc} \\ 158 \sim 159^{\circ} \mathrm{C} & 5 \mathrm{cc} \\ 159^{\circ} \mathrm{C} \text { 以上 } & \text { 少量 }\end{array}$

IV. アンモニアー酸性白さとの氣相處理 內径 $1.4 \mathrm{~cm}$ のガラス管に粒狀のアンモニアー酸性白上を $10 \mathrm{~cm}$ 程つ

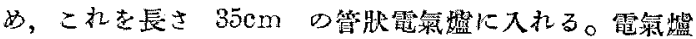
を加㠇すると酸性白土に吸䒴されている少量の水分が溜 出して来る。酸性白土をつめた部分加完全に $200^{\circ} \mathrm{C}$ に

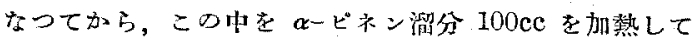
生じた蒸氣を徐々に通過させる。この間溫度は常に200 ${ }^{\circ} \mathrm{C}$ 保たせる。冷却器を通して溜出した油分を芒硝に て畭燥した後分溜する。

$\begin{array}{rr}\text { 沸點 } 156 \sim 157^{\circ} \mathrm{C} & 3 \mathrm{cc} \\ 157 \sim 158^{\circ} \mathrm{C} & 7 \mathrm{ce} \\ 158 \sim 159^{\circ} \mathrm{C} & 13 \mathrm{cc} \\ 159 \sim 160^{\circ} \mathrm{O} & 24 \mathrm{cc} \\ 160 \sim 161^{\circ} \mathrm{C} & 14 \mathrm{cc} \\ 161 \sim 162^{\circ} \mathrm{C} & 10 \mathrm{cc}\end{array}$

$$
\begin{array}{ll}
162 \sim 163^{\circ} \mathrm{C} & 8 \mathrm{cc} \\
163 \sim 164^{\circ} \mathrm{C} & 6 \mathrm{ce} \\
164 \sim 165^{\circ} \mathrm{C} & 5 \mathrm{cc} \\
165 \sim 166^{\circ} \mathrm{C} & 2 \mathrm{cc} \\
166^{\circ} \mathrm{C} \text { 以上 } & \text { 少是 }
\end{array}
$$

Isoborneol: 沸點 $159 \sim 160^{\circ} \mathrm{C} の_{n}$ カフェン溜分 $5 \mathrm{~g}$ を, $50 \%$ 硫酸 $0.5 \mathrm{~g}$ 及じ水醋酸 $15 \mathrm{~g}$ 上共に $50 \sim 60^{\circ} \mathrm{C}$ K2 時間加溫与る。水考加元て分離した燕色油分を充分

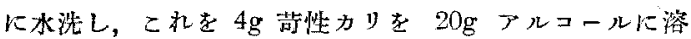

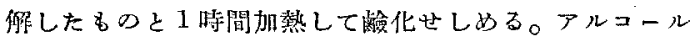
を盓い水蒸氣蒸溜に附し，溜出油分を放罷して扣くと絬 晶が析出する。石油エーテル上り再結晶。融點 $211^{\circ} \mathrm{C}$ (封管中)

\section{一文 獸 -}

1) Gurwitsch, Z. physik. Chem., 107, 235 (1923).

2) 桑田, 工化, 32, 1154 (1929).

3) 小島，日化，71，399 (1950)。

4) 山本, 大坪, 工化, 36, 447 (1933).

(昭和 25 年9月 11 、日受理)

\section{水和性鹽類水溶液の密度（補遺）}

\section{石川鐵 彌}

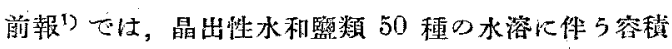

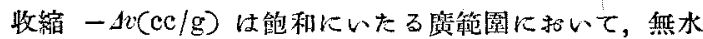
監の重量分卒 $z$ につ承数形 $K z(I-z)^{1+n}$ で表わされ ること，しかる $K$ は热水監 $1 \mathrm{~g}$ 當りの水和客穔に關聯 ある正の恒數であり， $m$ 泣 $1 / 2$ 在特儿含む自然数 0 , $1 / 2 ， 1 ， 2 ， 3 \cdots$ ‘゙あるるる表示したが，ただ硫酸ナト

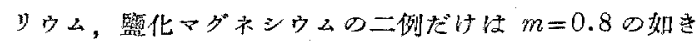
牛端の數值を與えたととについては敢て解れなかつた。 本稿で性先ずこの異例につき再检討を加えることにす る。

監化マダネシウム水溶液については，好都合にも－I.

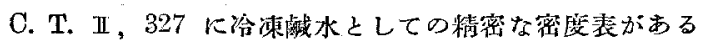
加ら，その $20^{\circ} \mathrm{C}$ ののにつき更めて吟味したが，筑 3 表の如く，5〜18\% までは $m=1 / 2 ， 19 \sim 30 \%$ (飽和 35 . $30 \%)$ では $m=0$ であることを認めた。 $K(m=1 / 2)=$ $0.2619, K(m=0)=0.2371$ とした場合の密度の平均䛊 差は $\pm 0.024 \%$ であつて, 同書揭載の $0^{\circ} \mathrm{C}$ に和ける $z$
の三次式による誤差 $\pm 0.03 \%$ 上りる假秀である。これ によつて監化マグネシウムは硫酸、グネシウム等と同一 形式に虽するものであることが確められた。

硫酸ナトリウム水溶液については，I. C: T. III，81 に

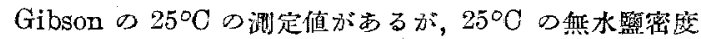

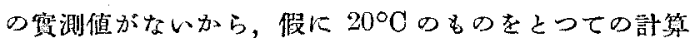
結果では、1 13\% では $K(m=1)=0.2652 \pm 0.0018$, $14 \sim 29 \%$ (饱和 $21.81 \%$ ) では $K(m=1 / 2)=0.2480 \pm$ 0.0005 上なり，共に十分な恒数性を認凶た。と北らに 上つて前報の第 2 表中 $m=0.8$ なる值は不邀虽な內捕法 による密度表を琳用したためであることが明嘹となつ た。硫酸ナトリウム氷溶液の䟴度に上る 既算の頤類には見られなかつたが，監化ナトリウム水溶 液について８温度の上昇に上つてての形式をとるてと，

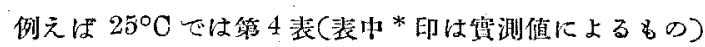
の如くであって，12\%までは $m=1$ ，それ以上 $26 \%$ (饱 和 $26.48 \%$ ま あ゙は $m=1 / 2$ となる。 